\title{
Otočani na malim otocima danas
}

\section{Vladimir Skračić}

Zadar

vskracic@unizd.hr

\section{UVOD:MALI NASELJENI OTOCI}

Već trideset godina sustavno se bavim istraživanjem jezične otočne baštine. Nema nijednog naselja na zadarsko-šibenskim otocima u kojemu nisam sâm ili sa suradnicima anketirao otočane, razgovarao s njima i boravio u njihovim domovima. I pitao se, naravno, čemu sve to služi. Ako se to čime se bavim smatra znanstvenim radom, automatski se postavlja i pitanje: čemu služe, s obzirom na sve što se događa na otocima, znanstvena istraživanja? A onda i znanstvena istraživanja općenito, osobito u području humanističkih znanosti. Nastavak toga niza pitanja završava u nebeskim prostranstvima i morskim dubinama i čini se najboljim odustati od traženja odgovora. Jedan jednostavan i ljudski svakako bi mogao biti: kada se nešto voli, ne pita se za smisao. A voljeti nešto, čak i bez razumnog objašnjenja, već ima neki smisao.

U ovom osvrtu riječ je o otočanima, ali prije svega o onima na malim zadarskim i šibenskim otocima. Ipak, u ovim razmatranjima moći će se prepoznati i otočani malih kvarnerskih, trogirskih otoka i Elafita, ali i oni s Cresa, Visa, Lastova i Mljeta, koji, iako mnogo veći, svaki iz svojih razloga žive u konstantnoj demografskoj regresiji.

Otočani malih naseljenih otoka ne mogu danas riješiti sami nijedno značajnije pitanje svoje egzistencije na otoku. Tako barem oni misle. Oni smatraju da bi svim građanima Republike Hrvatske trebala biti zajamčena egzistencijalna sigurnost, ma gdje živjeli: u dolinama rijeka koje poplavljuju, $\mathrm{u}$ brdima zametenima snijegom ili na udaljenim jadranskim otocima. To je načelo ugrađeno u hrvatski Ustav i u većinu zakonskih akata, od kojih je jedan i Zakon o otocima.

Često se u govoru o malim otocima zazivaju vremena kada su vjenčanja i krštenja bili redovita pojava, kada su škole bile pune djece, polja obrađena, a more puno ribe. Izvjesno je da se u nostalgičnom zanosu i mnogo pretjeruje. Ribe nije bilo uvijek ni za svakoga kome je bila potrebna, polja su bila mala 
i nedovoljna da bi nahranila sve seljane, u školama nije bilo mjesta za sve bez obzira na imovinski status i spol, umiralo se u ranoj mladosti i mnogo. Često od gladi. Ustvari i objektivno, mali naseljeni otoci bili su prenapučeni i sve što se iz današnje perspektive čini tako nostalgičnim nije sigurno tako izgledalo iz ondašnje. I mene su, s obzirom na moju dob, zahvatili repovi otočne bijede i neimaštine.

\section{KAKO SU I ZAŠTO NESTALI OTOČANI?}

Jednostavno pitanje na koje nitko ne želi iskreno odgovoriti glasi: kako se dogodilo da su svi, ili gotovo svi otočani, u godinama prosperiteta pobjegli na kopno? I na njemu ostali praktično sve do svoga umirovljenja, nakon što su tamo ostvarili gotovo sve svoje životne ambicije: naobrazbu, mjesto u društvu, stan u gradu, školovanje djece i, na koncu, kakvu-takvu mirovinu. Sav šarm života u osami otočnog naselja raspršio se tada pred zovom Jadranske magistrale, otvorenih granica, hotelskih kuća i tvorničkih hala, i svi su pohitali za vrijednostima koje danas sa sigurne distance obnovljene kuće (i groba) na otoku, bez mjere napadaju.

Za današnje stanje na otocima neosporna je odgovornost države. Često se zaziva Austrija i njezina otočna i uopće pomorska politika: svjetionici, lukobrani i rive, parobrodski promet, dužobalna plovidba, ribarski zakoni i ribarska politika, opskrba vodom - jednom riječju promišljen sustav zemlje koja želi biti prisutna na moru. Ako se međutim pažljivo čitaju na primjer dokumenti o ribarskim sporovima, jasno će biti svakome da ni ta austrijska politika, koja se iz današnje perspektive čini tako utemeljenom, mnogima nije bila ni dobra ni pravedna. No unatoč svemu čini se da je sve što je došlo poslije toga bilo gore. Prvi egzodus s otokâ koncem 19. stoljeća nitko nije mogao zaustaviti. Ni svemoćna austrijska pomorska politika, ni njezini dobro osmišljeni zakoni. Nitko na novonastalu situaciju nije imao odgovora. Objektivna prenapučenost i izostanak gospodarske osnove nakon pojave filoksere, demografski su poharali otoke. Budući da nacionalno kopno (ma što to značilo) nije moglo apsorbirati sve koji su krenuli u pečalbu, trebalo je naći neko drugo, daleko i prekooceansko odredište na kojem će se stvoriti uvjeti za novi život. U tom je kontekstu zanimljivo ustvrditi da su ti, uglavnom neuki otočani na novim adresama na kojima su se nastanili sva svoja znanja stečena na otocima, osobito u ribolovu i vinogradarstvu, u slobodnom i poduzetničkom svijetu afirmirali i unaprijedili gotovo do savršenstva, a i danas su u tim djelatnostima važni protagonisti. 
Jugoslavenska pomorska politika i tadašnja hrvatska, u mjeri u kojoj je bila hrvatska, doživljavala je otoke, more i obalu kao zlatnu koku za proizvodnju i prikupljanje uvijek nedostatnih deviza. Mastodontski hoteli na obali, brodogradilišta i industrijska postrojenja, pomorski promet i nikada uređeno ribarstvo bili su podređeni samo tom cilju. Opskrba vodom, elektrifikacija, izgradnja malih i primjernih pogona, obrtništvo te obnova lučke infrastrukture, škola i crkava išli su puževim koracima, bez plana i strategije. Otoci i otočani nisu prepoznati kao dio zajednice koji bi trebao očuvati jedinstveni položaj Jugoslavije u krilu mediteranskih zemalja, upravo onaj dio na koji se ta zajednica pozivala kada je htjela afirmirati svoju posebnost i mediteransku pripadnost. Otoci i otočani ostavljeni su na milost i nemilost nepostojećoj jadranskoj politici opterećenoj bezidejnošću i neinventivnim pokušajima nesustavne jadranske orijentacije. Preostali, još uvijek brojni otočani krenuli su poput većine tadašnjih građana prema kopnu i gradovima. Na otocima su ostali oni koji više nisu, uglavnom zbog svoje dobi i statusa, imali kamo.

Model obnoviteljske politike bivše Jugoslavije, industrijalizacija i infrastrukturno povezivanje te otvaranje radnih mjesta na kopnu, usisao je otočno stanovništvo, opustošio otočna naselja i pokrenuo stanje demografske regresije, koje traje do danas i ne nazire se dan kada će se ono promijeniti ni način na koji će se to dogoditi. Svi napori hrvatske države, prvi sustavni pokušaj integracije otoka i otočana u ravnopravan korpus hrvatskoga stanovništva, golema sredstva uložena u prometno povezivanje i objektivno poboljšanje sigurnosti boravka na otocima, nisu promijenili demografsku sliku ni kvantitativno ni kvalitativno. Štoviše, svi pokazatelji koji se odnose na to područje (dob stanovništva, broj novorođenih, broj djece u školama, broj aktivno zaposlenih) na svakom su sljedećem popisu sve lošiji. Čini se da je proces izmaknuo kontroli i da ga nikakvi programi i zakoni više ne mogu preokrenuti.

\section{ČEMU SE MOGU NADATI OTOČANI?}

Postoji nada da bi do promjene trenda moglo doći ulaskom Hrvatske u Europsku uniju, iako zasad nikome nije jasno kojom bi se to razvojnom politikom moglo ostvariti. Jedino što se u ovom trenutku čini realnim proces je koji se odvijao i bez naše europske pripadnosti, prodaja građevinskih parcela. Ako se na takvoj politici temelje nade u promjene, treba shvatiti one koji strahuju da bi preobrazba stanja na otocima mogla promjenom hrvatske pozicije članstvom u EU-u biti vrlo brutalna i dugoročno neprihvatljiva. 
Zastupnici priključenja Hrvatske EU-u vole reći kako se Hrvati vraćaju kući, to jest tamo kamo oduvijek pripadaju. U toj tvrdnji o povratku kući ipak ima istine, barem kad je riječ o otočanima koji se slobodno mogu pozivati na neprekinutu vezu s Europom i europskim duhom od antike do danas. I to ne zbog toga što morski kontakt nikada nije bio potpuno prekinut, nego upravo zbog toga što su morem pritjecali blagotvorni utjecaji s mediteranskih obala. Pa zašto onda strah od Europe? Problem nije u Europi, nego u nama. $\mathrm{U}$ trenutku potpune integracije s europskim prostorom mnogi će se Europljani uputiti prema hrvatskim otocima. I u tome nije problem. Dobro došli! Jer ako želimo biti pravedni, treba reći da tu nitko nije oduvijek. Pa ni mi! Svi smo jednoga dana ovamo došli, a izbor na otoke redovito je padao iz nužde: straha od progonitelja, osvajanja neokupiranog prostora, poboljšanja egzistencijalne osnove... Ono što izaziva strah i sumnjičavost nisu Europljani, nego hrvatska politika, koja i dalje bezidejno upravlja - po općemu mišljenju - najvrednijim i najatraktivnijim nacionalnim resursima. Kada bismo svoje goste mogli dočekati u uređenoj kući, i naša i njihova pozicija bile bi bolje i sigurnije. To se nije dogodilo i ne može se dogoditi, i to zato što ne postoji ni politička ni bilo koja druga snaga koja svojim autoritetom može definirati što želimo od svojih otoka u ovom trenutku.

Na hrvatskim otocima nije se nikada ili gotovo nikada živjelo po mjerilima europskoga blagostanja kako se ono danas razumije. Na otocima nikada ničega nije bilo napretek. U cjelini, na otocima se uvijek živjelo skromno i sa sviješću da niotkud ništa ne može doći što se svojim rukama na samome otoku ne može steći. Svi tajkuni i bogataši koji dolaze s hrvatskih otoka, osobito malih, stali bi na prste jedne ruke. $S$ druge strane, s pjesnicima, slikarima i znanstvenicima stvari stoje sasvim drugačije! I to ne čudi. Otok, a osobito mali otok, oduvijek je bio mjesto gdje se ništa nije moglo ukrasti ili sakriti, gdje je svaki odmak u ponašanju bio sankcioniran pravorijekom zajednice, gdje su ovisnost o susjedu, ma kakav bio, i solidarnost s njim bile pretpostavka opstanka. Bratovštine, zadruge, kase uzajamne pomoći i kunserbe samo su vanjske manifestacije unutarnje i stvarne potrebe za zajednicom.

\section{INZULARNA ILI KOPNENA HRVATSKA?}

Što činiti s otocima i otočanima? Trebaju li svoje probleme rješavati sami ili to treba učiniti netko umjesto njih? Ili zajedno s nekim? Prva bi na potezu trebala biti odgovorna država koja bi prije bilo kakva odgovora na otočna pitanja trebala odgovoriti na ono najjednostavnije: kakvu Hrvatsku želimo? 
Otočnu ili - nazovimo je tako - kontinentalnu? Još u prvim godinama samostalne Hrvatske izvlačili su se projekti iz ladica tzv. jadranske orijentacije. Plava magistrala, tako se to zvalo, trebala je mostovima povezati sve otoke i tako formirati prometnicu paralelnu s Jadranskom magistralom. Pojavila se ideja da se problem integracije otoka s kopnom riješi podmorskim tunelima. I za jedno i za drugo moglo bi se reći: nema problema! Danas je tehnički sve moguće, a ni zainteresiranih investitora neće manjkati. Postavlja se međutim pitanje u kakvoj ćemo to zemlji živjeti sutra kada Šolta, Brač, Hvar i Vis budu dio kopna. Postoji li ijedan drugi način da se na otocima zadrži aktivno stanovništvo i da se na njima, upravo zato što su otoci i što čitavi svijet tu činjenicu percipira kao veliku blagodat, organizira život po mjeri otočana? Bacimo li pogled na otoke s mostovima i na procese koji su se na njima odvijali, mogli bismo se zapitati je li most (ili sutra tunel) najbolje rješenje ili, barem, je li most u svim slučajevima najbolje rješenje? Objektivno, svaki slučaj valja promatrati zasebno, no ne mogu se ne primijetiti razorne posljedice jednostavne dostupnosti otoka na integritet i identitet naselja koja su se, koje prije, koje poslije, povezala mostom. Istina je, s druge strane, da su mnoga od tih naselja, na račun gubitka svoje otočnosti, sačuvala ili dobila s kopna veliki broj aktivnih stanovnika.

\section{NEKONZISTENTNA DRŽAVNA POLITIKA:PRIMJER KORNATA}

Kao primjer nekonzistentne državne politike uzet ću Kornate, prostor gdje sam odrastao i koji aktivno pratim i danas kao građanin, Kurnatar i znanstvenik. Taj je jedinstveni arhipelag, točnije njegove dvije trećine, 1980. proglašen nacionalnim parkom i stavljen pod najstroži režim zaštite. Bilo je mnogo razloga da se tom proglašenju pristupi oprezno, uz ostalo i zato što su u prostoru zatečeni nespecifični stanovnici s domicilom na susjednim otocima, koji su usto još bili (i danas su) vlasnici kopna pod zaštitom. Ostavit ću po strani sve propuste koji su napravljeni tada i prema zaštiti i prema tradiciji i prema iskustvu Kurnatara, i sve sporove sa susjedima u koje su oni protiv svoje volje uvučeni zbog takve odluke. Prateći tisak, reklo bi se da su jedini realni problem zaštite toga prostora danas Kurnatari. Oni pale krš, neovlašteno love ribu, grade mule i uređuju kuće bez dozvole... 


\section{KORNATI - VEZA S KOPNOM}

Jedan primjer. Svaki otočanin danas mora priznati da su veze s kopnom znatno bolje nego nekada. Najmanje što se može sa sigurnošću ustvrditi jest da su svi naseljeni otoci javnim prijevozom povezani s kopnom. Ta činjenica nije, nažalost, promijenila demografsku strukturu otočnih naselja, ali je nedvojbeno onima koji su ostali olakšala život. Jedino Kurnatari do svoga posjeda na otocima moraju vlastitim brodom, i to pod izlikom da je riječ $\mathrm{o}$ nenaseljenom arhipelagu. To što $\mathrm{u}$ tom arhipelagu ima više od trideset tradicionalnih porata s nekoliko stotina domaćinstava oko kojih je strukturirano - doduše zapušteno - kornatsko gospodarstvo i što se devet desetina općine Murter-Kornati nalazi u arhipelagu, izvan matičnog otoka, nije bilo dovoljan argument da nam se osigura kakav-takav javni prijevoz, barem jednom tjedno. Kurnatar koji danas želi održati bilo kakav odnos sa svojim posjedom mora imati svoj brod (sa svim troškovima) te mul u domicilnom naselju i mul u Kornatima. Možda Kornati po demografskim kriterijima i jesu nenaseljeni, no činjenica je da u njima dnevno živi više stanovnika nego na mnogim malim naseljenim otocima. No za državnu administraciju to nije nikakav argument. Da ironija te prijevozničke drame bude potpuna, odnedavno su mnogi Kurnatari prijavili svoje stalno prebivalište u Kornatima te su ipso facto nastanjeni u mjesnom odboru Kornati. A i sama se općina zove Murter-Kornati.

\section{KORNATI - LABORATORIJ APSURDA}

Drugi primjer. Što se događa u akvatoriju i na morskom dnu koji su pod najstrožim režimom zaštite? Deklarirano je jedan od ciljeva svakoga nacionalnoga parka, na moru i na kopnu, rekreacija i posjećivanje. Kako je taj segment organiziran na Kornatima? U ovom je trenutku, prema informacijama koje dolaze iz Plana upravljanja NP Kornati, na pet lokacija identificirana za pridnenu floru smrtonosna alga Caulerpa racemosa. Taj broj lokaliteta izvjesno nije konačan jer istraživanjem nije obuhvaćeno ukupno podmorje nacionalnoga parka. Danas je općeprihvaćeno da se ta alga prenosi sidrenjem, a ne parangalima i baligotima. U svakom tradicionalnom portu koji je Pravilnikom NP-a određen za boravak turističkih plovila, u ljetnim mjesecima sidri se na desetke brodova. Nijednim dokumentom, ni znanstvenim ni empirijskim, nije nikada utvrđen kapacitet tih uvala ni njihova ekološka izdržljivost. Da apsurd bude potpun, NP Kornati prije nekoliko je godina naručio, platio i dobio elaborat o privezištima u kornatskim uvalama, 
koji isključuje sidrenje kao način boravka, izvlači brodove iz najplićeg dijela uvala te im osigurava vez u kombinaciji bova plus obala. Rezultat: ništa. Posjećivanje $\mathrm{tz}$. turističkim brodovima na jednodnevnim izletima ima sve elemente posjećivanja osim jednoga: upoznavanja s vrijednostima NP-a Kornati i očuvanja prirode. Ni na jednom od brodova ne nalazi se profesionalni (ovlašteni) vodič, ne postoji nijedna točka na kojoj bi se posjetitelji educirali o vrijednostima Parka, ne postoji nijedan posjetiteljski program osim ručka od zaleđenih skuša... Masa od nekoliko tisuća izletnika dnevno u ljetnim mjesecima za sobom ostavlja golemu količinu smeća. No nisu bezazleni ni mali brzi brodovi s obale na jednodnevnim izletima (gumenjaci i sl.) koji u svojim plovilima nemaju nikakve sanitarne uređaje, dok čitavi arhipelag pod zaštitom nema nijedan javni sanitarni čvor.

\section{KAKO SE MOGLO OČUVATI KORNATE I KURNATARE?}

Umjesto da se $\mathrm{u}$ sustav zaštite uvelo Kurnatare zatečene $\mathrm{u}$ arhipelagu, iskoristilo njihovo minuciozno iskustvo, educiralo njih i njihovu djecu za novo doba i nove potrebe te uvelo dragovoljce i volontere u sustav čuvanja i afirmacije kornatskih vrijednosti, država je jednim anakronim modelom upravljanja, koristeći se rukovodećim mjestima kao sinekurom za svoje stranačke kadrove, modelom upravljanja i nadzora koji je jednak na velebitskim pašnjacima i Plitvičkim jezerima, instalirala bezidejnost kao trajni način ponašanja. Nikome nije bilo dopušteno, ma kako empirijski bio upućen u kornatsku stvarnost i ma kako bio educiran (ili oboje), da utječe na promjenu ponašanja. A bilo je bezbroj pokušaja. Istina o Kornatima danas jest da je stanje onečišćenja nerazmjerno gore nego u trenutku proglašenja Kornata nacionalnim parkom, da je u Kornatima deset puta manje Kurnatara, ribara i težaka nego tada i neizrecivo više posjetitelja koji su, kako sada stvari stoje, postali jedini smisao njihova postojanja. No ni oni sami po sebi nisu problem. Najčešće je riječ o ljudima osviještenim u pogledu zaštite. Ukratko, postojeći model upravljanja zaštitom jednostavno je atrofirao i vodi Kornate prema tzv. turističkom proizvodu bez identiteta. A takvo stanje prijeti i drugim otocima, osobito malim.

\section{OTOČANI I OTOČNOST DANAS}

Što žele otočani $i$, još preciznije, što žele otočani s malih otoka? Prvo što treba utvrditi kada je riječ o životu na otocima, a osobito o životu na malim otocima, jest da su otočani kao i svi drugi svoja ognjišta, o kojima danas 
govore s nostalgijom, napustili u trenutku kada se ukazala prigoda i stvorili uvjeti za bolju i sigurniju egzistenciju na drugome mjestu: u gradu, u Europi ili u prekomorskim zemljama. Osim u slučaju prvog egzodusa otočane na odlazak u načelu nitko nije tjerao. Odlazak je gotovo isključivo bio izbor njih samih ili njihovih roditelja koji su im željeli osigurati ono što se smatralo boljim životom. Kada se stvari pogledaju iz takve perspektive, nitko ne bi trebao biti dužan da im sada, na mjestu na koje se vraćaju, osigura uvjete u čijoj izgradnji u načelu nisu sudjelovali. $S$ druge strane, unatoč svim slabostima, treba konstatirati i to da je danas sigurnost boravka na otocima nerazmjerno veća nego u vrijeme kada je većina napustila otoke. Ako ostavimo po strani sve suvremene načine komuniciranja, dostupne svima, na isti način i na svakoj točki (mobilne veze, televizija i radio, hitne intervencije), treba reći da je u najvećem broju slučajeva povezanost s gradom brža i bolja te su struja, opskrba i zdravstvo sigurniji. No ipak, nezadovoljstvo je potpuno.

Ono čega nema na otocima ne postoji ni na mnogim drugim točkama hrvatske države. Opća demografska struktura stanovništva katastrofalna je, a ona na hrvatskom selu, u Lici i Slavoniji npr., teško da se i u čemu bitnom razlikuje od situacije na malim otocima, s tim da, gledano sa stajališta materijalnih očekivanja, mnogim otočanima turizam donosi prihode kojima se ne mogu nadati ni Ličani ni Slavonci. Pa što onda hoće otočani? Jesu li to još bolje veze s gradom i sa susjednim otocima, sigurna doprema vode $s$ kopna, više vezova za njihove brodove, još bolji televizijski signal...? Imaju li na to pravo? Imaju. Je li u tim nedostacima razlog svakim danom sve manjeg broja otočana na otocima? Nije. Kada bi svi ti i brojni drugi uvjeti koji se iz dana u dan množe bili ispunjeni, stanje se, po nama, ni u čemu bitnom, a osobito ne u demografskom pogledu, ne bi promijenilo.

Tome je mnogo razloga. Prvi je taj što je golemi broj otočana odgojen u preziru prema mukotrpnom i nesigurnom životu na otoku. Neki od njih u zrelim su godinama, osiguravši egzistenciju na kopnu, to zaboravili i vratili se na otok. Drugi se toga nisu nikada sjetili, niti su kod svoje djece izgradili sustav vrijednosti koji bi ih tamo vratio. Sljedeći je razlog otok kao takav. I hrvatska imenica otok i druge u mnogim jezicima, derivirane iz latinske imenice insula, uključuju u svom sadržaju odvojenost od drugih, zatvorenost u mikrosvijet okružen morem, nedostupnost itekako važnih materijalnih i duhovnih sadržaja koji su onima, drugima, na kopnu i u gradu dostupni. Zato bi mnogi sebi trebali priznati da sa svoga otoka nisu krenuli samo iz materijalne nužde. U odluke o odlasku upleteno je bezbroj razloga koje nije moguće nijednom znanstvenom metodom kvantificirati! 
Tražiti danas od otoka da se na njima u svim pojedinostima živi kao na kopnu potpuno je nerealno. Takav je zahtjev negacija otočnosti kao takve i inzularne Hrvatske kao geografske činjenice. Nitko ne može dati, pa bio i najljepši na svijetu - da parafraziram jednu francusku poslovicu - ono čega nema. Ukratko: otok nije kontinent. Da ne bih ostao nedorečen, ovaj bi stav ipak trebalo malo obrazložiti. Trebalo bi biti pošten i priznati da je život na otoku neka vrsta izbora za sve osim za one koji ga nikada nisu napuštali i koji ni na jednome drugome mjestu nisu osigurali egzistenciju. Njihov glas za promjene morao bi se najdalje čuti, a često nije tako. Oni su ili umorni ili rezignirani ili jednostavno pomireni s činjenicama kakve jesu. Ima nešto što je teško reći, a što je ipak točno. Svi napori koje čini država i pojedinci za tzv. vraćanje života na otoke vrlo izvjesno nemaju nikakva izgleda, osobito ako se pod tom sintagmom misli na povratak mladog i fertilnog stanovništva. Takav govor mogao bi se podvesti pod neku vrstu licemjerja. Realno gledajući, svi napori koji se danas čine za tzv. oživljavanje otoka u funkciji su sigurnosti boravka jedne, gotovo isključivo umirovljeničke, malo otočne, malo gradske populacije, čiji je obnoviteljski potencijal u vraćanju života na otoke ravan nuli. Bilo bi svakako nepoželjno iz tako brutalne konstatacije zaključiti da umirovljeničkom korpusu treba oduzeti sigurnost na koju računa. Štoviše, treba je unapređivati svakim danom. No to ne smije biti razlog za zamagljivanje činjeničnoga stanja i utvrđivanja istine. Ostavljajući po strani čistu faktografiju koja je uglavnom poznata iz popisâ stanovništva i koja sama za sebe mnogo govori, na ovom bi mjestu trebalo upozoriti da se u raspravama o povratku manipulira. I da u tom kontekstu valja razmotriti dvije skupine zabluda. Prva je, simbolično kazano, da količina i brzina brodskih pruga, sigurnost opskrbe vodom ili bolji signal neće vratiti mlade žitelje na male otoke. A druga je da se za poboljšanje stanja na otocima ne mogu izboriti oni koji imaju rezervnu lokaciju za život na drugome mjestu. Samo oni kojima je otok jedini izbor imaju neprijeporni autoritet u postavljanju novih zahtjeva. Svi ostali mogu samo pomagati ako žele i ako se to od njih uopće traži.

No kako to izgleda u praksi? Tko su ti koji imaju neprijeporni autoritet otočana? Postoje otoci u zadarsko-šibenskom arhipelagu gdje nema dostupne osobe u naselju koja može u svakom trenutku primiti cimu ili dostaviti poštu, otočana koji ni sami sebi ne mogu pomoći. Drugim riječima, licemjerno je od njih očekivati da artikuliraju svoje zahtjeve i da snagom potrebita čovjeka željnog promjena nastupaju pred institucijama koje odlučuju o njihovoj sudbini. Ukratko, sami su preslabi i ništa ne mogu učiniti bez pomoći sa strane. I tu se krug zatvara. Otočani ne mogu sami, a oni koji bi eventual- 
no mogli i znaju nisu na otoku i nemaju legitimitet. No ako se uključe i kada se uključe, s pozivom ili bez njega, to nisu mladi koji sa svojim obiteljima planiraju život na otoku, već najčešće oni koji se iz perspektive skorog umirovljenja pripremaju za ostatak života na otoku. Kako onda dalje?

Da bismo došli do odgovora, počnimo od najevidentnije činjenice da otok nije kopno. Svatko tko se našao na otoku, svojom voljom ili slijedom okolnosti, mora osvijestiti i činjenicu da se našao u prostoru koji uza sve slabosti ima i jednu neizmjernu prednost, dostojnu da neutralizira spomenute slabosti. Svaki je otok jedinstven, kako u svome prirodnom izgledu, svome društvenom ambijentu, tako i u svojim urbanističkim i estetskim rješenjima. Iako se to čini nedovoljnim, svakome tko njeguje i prepoznaje taj osjećaj, u načelu, život na otoku nije muka.

\section{MJESTO NEOTOČANA}

Vratimo se sada onima brojnijima, onima koji, iako žive drugdje, nikada nisu zaboravili svoje ishodište, niti ih je napustila želja da na neki način sudjeluju u otočnom životu, koji ne uključuje nužno i trajni boravak na otoku. U toj sam brojnoj skupini i sâm. Mnogi žive u najbližim gradovima na kopnu, a još ih je više razasuto diljem Hrvatske i svijeta. Među tim svijetom otočnih zaljubljenika mnogo je onih koji nisu otočani ni po kojem kriteriju, a otocima su posvetili svu svoju ljubav, znanje i vrijeme prateći i istražujući fenomene koji se mogu naći samo na otocima, specifično na hrvatskim otocima. Što oni mogu učiniti za male otoke?

Ovdje se neizbježno vraćam pitanju o smislu znanstvenog istraživanja i osobito znanstvenih istraživanja na otocima, koje sam postavio na samom početku. Kad ovo kažem, ne pitam sebe ima li to smisla jer ja sam o tome davno odlučio. Ono što me iskreno zanima jest što o tome misle otočani na otocima, koji često sumnjičavo prate zanimanje znanstvenika za njih, njihovo iskustvo i njihovo znanje. Koliko sam puta čuo dobronamjerno, gotovo sažalno pitanje od svojih tada mahom starijih ispitanika: »Ma što će ti to, sinko? Kome to triba i koga je briga za 'vo? « Pokušat ću na nekoliko primjera iz vlastite znanstvene i neznanstvene prakse pokazati što sam radio i kakve je to posljedice imalo. I neću ni tražiti ni dati odgovor na pitanje svojih ispitanika.

\section{Centar za jadranska onomastička istraživanja: Onomastica Adriatica}

Potaknut demografskim stanjem na malim otocima, a osobito zadarskim i šibenskim, svjestan da će odlaskom posljednjih otočana moje generacije i 
generacije čije sam dijete nestati i sve blago pohranjeno u njihovoj memoriji, počeo sam popisivati dio jezične baštine koja se odnosi na geografska imena - toponime. Od sredine osamdesetih godina 20. stoljeća do danas razgovarajući s brojnim ispitanicima, prikupio sam sa svojim suradnicima sve toponime na zadarskim i šibenskim otocima i Pagu. Riječ je o skupu od oko 15.000 jedinica. Sva su ta imena i otočni kontekst u kojemu su ona nastajala i žive objavljena u sedam monografija, a posljednja, osma, još neobjavljena, bit će upravo ona o šibenskim otocima. No to nije sve kada je riječ o tim otocima. Prije deset godina utemeljio sam na Sveučilištu u Zadru Centar koji od 2003. provodi takva istraživanja u okviru znanstvenoga projekta Onomastica Adriatica. A tako se zove i biblioteka u kojoj su objavljene spomenute monografije. Unutar projekta i Centra formirao se tim mladih stručnjaka koji će sigurno, na ovaj ili onaj način, nastaviti istraživanja na hrvatskim otocima, velikim i malim. Osim na suvremenu toponimiju svoja smo istraživanja proširili na povijesnu toponimiju i leksik. U ovom trenutku pripremaju se dva doktorata vezana uza zadarski i šibenski otočni prostor. Jedan se bavi nazivima ptica, drugi biljkama, dok su podaci o ribama već prikupljeni (anketom) i predstoji nam rad na objavljivanju atlasa riba. Konačno, pripremamo upitnike za izradu pomorskoga jezičnog atlasa (ribe, arti, način lova, brod, oprema i plovidba, drvena brodogradnja i sve što spada u to područje). Kada sve bude gotovo, a realno vrijeme u kojemu se sve to može dogoditi ne bi trebalo biti duže od četiri do šest godina, šibenski i zadarski otoci dobit će jezičnu osobnu iskaznicu kakvu nema nijedan drugi arhipelag na Jadranu, a nema ih mnogo ni u svijetu.

U trenutku sveopćih pojednostavljivanja i instant svačega, koje većina ljudi naziva globalizacijom, iznimno je važno da iz svoga otočnog, naizgled skromnog i često marginaliziranog inventara znanja i vještina pokažemo ono što svi na svijetu, osim nas samih, prepoznaju kao veliku vrijednost. Objasnit ću to poslije na jednom primjeru, ali bih prije postavio pitanje na koje odgovor može dati samo otočanin. Kojim je sve znanjima otočanin (nekada) morao biti naoružan: gradnja i održavanje broda, plovidba, jedrenje i veslanje; sve vrsti ribolova, malog i velikoga, pravljenje i održavanje svih ribarskih alata, tretman ribe: leđenje, sušenje i soljenje; gradnja u suho: pregradni zidovi, mocire stanovi, muli lepari; uvećavanje posjeda krčenjem, brudanjem i rapanjem; tretman od sijanja do konzerviranja svih poljoprivrednih kultura; održavanje i tretman stada sa svim proslavama koje to prate. Tim znanjima ne iscrpljuje se ukupni etnološki proizvod zajednice; tu su još svi eminentno ženski poslovi: osim onih vezanih uz obitelj još i tretman vune, pređa i pletenje, izrada cipela, pranje odjeće na perilišćima, šivanje i tako redom. 


\section{Latinsko idro}

Vodeći se mislima o nekadašnjim znanjima i sposobnostima otočana, pokrenuo sam s još nekoliko istomišljenika prije petnaest godina regatu na jedra. Svima je poznato da su Murter i Betina, zbog svoga golemog prekomorskog posjeda u Kornatima, na Modravama i u Makirini, imali, a imaju i danas, najveću flotu malih drvenih brodova na Jadranu. No dolaskom motora u šezdesetim godinama 20. stoljeća, gotovo su sva jedra završila u konobama, magazinima, šufitima ili potpuno nestala. Pripremajući tu prvu, mogu slobodno reći eksperimentalnu regatu - jer se u Murteru nije nikada regatavalo na jedra - jedva smo, kombinirajući jedra, lantine, jarbole i timune s različitih brodova, opremili sedam posada. Danas se na Latinskom idru $\mathrm{u}$ Murteru koncem rujna nađe u prosjeku više od sedamdeset brodova s cijelog Jadrana. Sašivena su nova jedra, obnovljeni ili napravljeni novi jarbuli, lantine, konopi, vesla i timuni... sagrađeno je ili obnovljeno nekoliko novih gajeta i leuta i jedna škloska. Uključili su se svi: starci, djeca i žene; istraživači, amateri, pjevači... i, što je najvažnije, po čitavom se Jadranu osnivaju slične udruge i organiziraju slične manifestacije (do danas dvadesetak). Regate prestaju biti same sebi svrhom i postaju mjesto sjećanja, obnove i afirmacije maritimne i svake druge otočne baštine. I ne samo fizičke već i one isto tako važne, nematerijalne, pohranjene upravo $u$ memoriji onih najstarijih, nemoćnih, ali zato itekako važnih članova zajednice. Nekima od njih, prema vlastitim iskazima, ovi su događaji bez obzira na njihovu dob život učinili smislenim, a nama su svima pokazali da je riječ o vrijednostima kojih ni sami nismo bili svjesni.

\section{Arhipelogos}

No najvažniji i za sada najneuspješniji projekt zamislio sam prije pet godina dok sam bio na dužnosti prorektora za znanost i razvoj na Sveučilištu u Zadru. U osnovi projekta stajale su dvije činjenice: jedinstveni prostor (arhipelag i zaobalje) i profiliranje Sveučilišta kao jadranskoga i istraživačkoga. Imenom su te odrednice bile iskazane u kovanici ARHIPELOGOS - $u$ slobodnom prijevodu: arhipelag i znanje. Smatrao sam da se po mnogobrojnim napuštenim vojarnama, školama, društvenim domovima i sličnim prostorima mogu organizirati terenska istraživanja, znanstveni kampusi, ljetne škole i studijski boravci, bilo kao dio postojećih sveučilišnih programa, bilo kao potpuno novi programi samostalno ili u suradnji s drugim znanstvenim, domaćim i međunarodnim institucijama. U kontekstu ovoga osvrta o malim otocima i mjestu koje zauzima staračko domicilno stanovništvo, 
važno je napomenuti da je svaki pojedinačni program uključivao radionicu sa starosjediocima, koji su svoja iskustva života na otoku, svoja znanja i vještine trebali prenositi polaznicima. Zanimljivo je da je projekt dobio golemu podršku svjetskih uglednih sveučilišta (Barcelona, Harvard, Graz, Padova, Pisa, Sorbona) i mnogih drugih s kojima smo bili u kontaktu. Iako je institucionaliziran kao dio sveučilišne znanstvene strategije, projekt je $\mathrm{u}$ suštini propao. Zakazala je državna administracija, unatoč eksplicitnoj podršci Ministarstva znanosti. Nikada nismo dobili objekte na upotrebu unatoč obećanjima i ogromnim naporima koje smo u to uložili. S druge strane, iako smo sami sastavili vrhunski tim stručnjaka, nikada nije došlo do operacionalizacije predloženih programa. Možda će to biti moguće u nekom drugom vremenu, mada mi se čini da svako nestandardno razmišljanje o otocima i njihovoj sudbini za sada nema velikih izgleda.

\section{Kurnatari}

Mada sam, objašnjavajući nekonzistentnost državne politike u zaštiti prostora, već spomenuo Kornate, htio bih u kontekstu ovoga teksta o revitalizaciji života na otocima napisati još nekoliko riječi o tom specifičnom prostoru i zauzimanju za njega. Kako bismo kao vlasnici i stanovnici izbjegli stihijski reagirati na poteze resornih ministarstava i uprava odgovornih za promjenu stanja u prostoru i našega položaja, osnovali smo udrugu za zaštitu vlasničkih prava i autentičnih kornatskih vrijednosti pod imenom Kurnatari, čiji sam predsjednik od osnutka 2000. godine. Od tada do danas reagirali smo na sve dokumente koji su doneseni, pokretali brojne inicijative i upozoravali na neodrživost postojećeg modela upravljanja. Svi su ti pokušaji ostali bez rezultata. Pokazalo se i u ovom slučaju da bilo koji projekt ili inicijativa koji se odvija izvan utjecaja države, može imati veći ili manji uspjeh. No kada vam je nezaobilazni partner država ili njezine institucije, ne smijete ni na što računati. To je još samo jedno upozorenje da bi svi poticaji i inicijative za promjenu odnosa trebali dolaziti od otočana i onih kojima su otoci na srcu. Tamo gdje se javlja država kao nezaobilazni partner slabi su izgledi za uspjeh.

\section{DRUGI PROJEKTI}

Do sada sam $\mathrm{u}$ tekstu naveo inicijative $\mathrm{u}$ kojima sam sudjelovao ili sam bio njihov pokretač. Niti sam osamljen u tim nastojanjima niti su to jedina područja u kojima zainteresirani danas djeluju. Unatoč nikada nerazriješenim pitanjima postojanja i djelovanja na otocima, mnogo je toga dobroga 
napravljeno u sferi onoga na što istraživači i njihovi timovi mogu utjecati, često s izvanredno skromnim sredstvima. Dobar je primjer rad projektnog tima Instituta za migracije i narodnosti koji je značajno pridonio demografskim istraživanjima na hrvatskim otocima. Neki geografi, arheolozi, povjesničari i povjesničari umjetnosti, botaničari i ihtiolozi izradili su nevjerojatno bogatu, iako za sada možda neusustavljenu, dokumentaciju o svojim otočnim istraživanjima. Kvaliteta nekih lingvističkih atlasa iz sfere proučavanja ribljih naziva dotiče sam svjetski vrh. Od prošle godine imamo sustavno popisana i sva poznata podmorska arheološka nalazišta. U posljednjih desetak godina objavljeno je isto toliko rječnika lokalnih govora sa šibenskih i zadarskih otoka (Iž, Kolan, Kukljica, Kun, Murter, Povljana, Rivanj, Sale, Zlarin; otprije Vrgada), dnevno se osnivaju družine koje njeguju glagoljaško i klapsko pjevanje (Preko, Jezera, Iž, Murter), razvija dramski amaterizam, njeguju lokalne specifičnosti (lončarstvo, čipka, ulja, vina, prehrambeni specijaliteti i sl.). Javnost o svemu tome zna malo ili ništa. No stanje nije bitno bolje ni s poznatošću drugih istraživanja, na kopnu i na moru, osim ako nije riječ o medicini ili novim tehnologijama. Ni hrvatski građani općenito, ni otočani posebno, a često niti sami istraživači u tim rezultatima ne vide nikakav doprinos promjeni stanja, stanja koje je objektivno teško, ali koje - valja i to priznati - nikada nije bilo bitno drugačije. Iz toga se, naravno, nikako ne smije zaključiti da treba ostati ovakvim kakvo je danas.

\section{KAKO HRVATI DOŽI VLJAVAJU OTOKE?}

Hrvatska država s obzirom na svoju površinu ima razmjerno jednu od najdužih obala na svijetu s jednim od najvećih broja otoka. Površini nacionalnoga kopna odgovara površina hrvatskoga teritorijalnog i epikontinentalnog mora. Na hrvatskim su otocima nastajale, a negdje se i održale, najprepoznatljivije institucije nacionalnog identiteta, a povijesno hrvatsko ribarstvo, solarstvo i brodarstvo autentični su svjedoci naše pripadnosti Mediteranu. Moglo bi se reći: »E pa što?« I drugi su hrvatski krajevi, svaki na svoj način, dali doprinos onome što smatramo hrvatskim nacionalnim identitetom. I to je točno! No ono što nije točno, odnosno što je krivo kada je riječ o otocima, to je da danas Hrvati i hrvatska politika otoke najčešće doživljavaju kao problem, kao nepotreban trošak, uzaludno rasipanje državnog novca na premali broj otočnih stanovnika: brodari u gubicima, školstvo i zdravstvena zaštita neprimjereno skupi, hitne intervencije također i sl. Istodobno, danas nema Hrvata koji nešto znači u političkom životu, a da se ne poziva na more i otoke kad govori o prepoznatlivosti svoje domovi- 
ne. Nema toga turističkoga sajma u svijetu na kojemu Hrvatska turistička zajednica ne poziva goste upravo slikama s hrvatskih otoka (zalasci sunca, suhe smokve, rasparane mreže, ruzava sidra, požutjela jedra, slane srdele, salata od hobotnice, tirkizno more). Nikada nitko nije pokušao izračunati, a i neće, koliki je doprinos tih zapuštenih ljepotica s onemoćalim staricama i starcima tzv. hrvatskome turističkom proizvodu i jesu li ikada otoci dobili, ako ne onoliko koliko su dali, barem onoliko koliko im je egzistencijalno potrebno. Umjesto toga prezir i, od prilike do prilike, zavist.

\section{TKO I KAKO MOŽE POMOĆI?}

Može li se stanje na malim otocima zadarskog i šibenskog arhipelaga promijeniti i na koji način te, još preciznije, u duhu ove rasprave, koje je mjesto u tim promjenama otočana, poduzetnikâ i istraživačâ? Već smo utvrdili da su otočani malobrojni, stari i uglavnom nemoćni da utječu na promjene. Gospodarstvenici, čija je jedina mantra profit, ne vide, bez značajnih poticaja, svoj interes u ulaganju u otoke. Pitanje je što bi se dogodilo i kada bi se netko zaputio s megalomanskim projektima prema tako fragilnim zajednicama, kakvih je najava bilo. Ono što bi gospodarstvenici mogli, ali još uvijek u Hrvatskoj o tome ne postoje ni svijest ni bilo kakav program, bilo bi organiziranje uvjeta za rad malih, sofisticiranih i tehnološki prilagođenih projekata s malim brojem dobro obrazovanih sudionika, za koje s obzirom na suvremeno stanje komunikacijskih tehnologija blizina kopna nije nužna pretpostavka.

No trebao bi postojati drugi, možda sporiji, ali svakako sigurniji put, a to je obrazovanje. Obrazovanje za otoke. Ono u početku ne mora biti institucionalno, a može se djelomično i institucionalizirati, počevši od zavičajnih čitanki, školskih radionica te uključivanja djece u već postojeće programe i manifestacije. U Murteru smo već krenuli tim putem. Unutar Latinskoga idra postoji i Malo Latinsko idro, i nova školska gajeta, te odvojene dječje regate na jedra i vesla. Razmišljam u posljednje vrijeme sa svojim suradnicima o pokretanju programa pod radnim nazivom Otočna obrazovna ambulanta, koji bi se sastojao u tome da grupa stručnjaka, zajedno s lokalnim stanovništvom, organizira po otocima radionice i predavanja o otočnoj baštini svih vrsta. Dok sam bio na sveučilištu, pokušao sam sa suradnicima iz Centra za jadranska onomastička istraživanja pokrenuti diplomski studij iz adriatistike, discipline unutar lingvistike, koja bi se isključivo bavila jadranskim leksičkim nasljeđem i suvremenom jezičnom problematikom. No to nije uspjelo i vjerojatno neće. 
No ono što bi neprijeporno moglo dovesti do promjena na otocima općenito i posebno na malim naseljenim otocima bilo bi upoznavanje hrvatske javnosti, djece i odraslih s njihovim postojanjem. Nacionalna televizija $u$ zemlji s više od 1200 otoka i gotovo 6000 kilometara litorala posvećuje moru i otocima 25 minuta tjedno. Siguran sam da i drugi krajevi u Hrvatskoj imaju prigovor na svoju zastupljenost u programu na HTV-u, ali ipak mislim da je riječ o golemom propustu. Prateći naše medije i način na koji govore o moru i otocima, pitamo se jesmo li mi uopće pomorska zemlja i bi li bilo bolje da šute. Je li zaista smisao mora u tome da turisti mogu do njega što prije doći, diviti se najljepšim zalascima sunca i uživati u pečenoj ribi? Apsolutno je potrebno gostima osigurati ugodan boravak. Oni to, uostalom, za svoj novac i očekuju. No postavlja se pitanje koje je mjesto domaćina u toj predstavi. Možda i oni to zaslužuju. Mi svoju zemlju i svoje otoke moramo najprije urediti zbog sebe. Popisati i valorizirati što imamo, napraviti registar neobavljenih poslova, educirati mlade i potaknuti istraživače. Pomoći svima koji su se dokazali: učiteljima, djeci, otočnim entuzijastima, amaterima i sakupljačima otočne baštine. Odgovornost medija, a posebno televizije, $\mathrm{u}$ tom je poslu ogromna.

\section{ZAKLJUČNO RAZMATRANJE}

Naše je mišljenje da u postojećim uvjetima nikakva obnova stanovništva prostom prokreacijom za dugo vrijeme nije moguća i da je san o malim otocima s mnogo djece pusta iluzija. No ono što je moguće i u čemu i otočani i poduzetnici i istraživači mogu naći svoje mjesto revitalizacija je otočnog prostora i života. Ako svi priznaju da su otoci i osobito mali otoci biseri hrvatskoga Jadrana i jedna od najvećih posebnosti $\mathrm{RH}$, onda i institucije $\mathrm{i}$ otočani i istraživači trebaju ići za tim da njihova ljepota ne izblijedi i njihov duh ne nestane. Mali otoci ne mogu opstati bez komunikacije s kopnom. Tako je bilo u prošlosti, tako je i danas. Najave da bi se svi otoci trebali naći u istoj administrativnoj jedinici političke su spekulacije neupućenih, bez uporišta u prošlosti i u suvremenosti. Smjer kojim su se razvijali odnosi između kopna i otoka simbolično je prikazan strelicama za buru u vremenskoj prognozi. Iako je privlačnost kopna u jednom trenutku presudila malim otocima i otočanima, ipak je i danas simbioza jedina realna činjenica na kojoj se mogu graditi promjene. Uvijek su postojali takvi specifični sadržaji koji su se mogli ostvariti samo u gradu i samo na otoku. Prije nekoliko godina Nikola Bašić, naš eminentni arhitekt i dokazani poznavatelj i promicatelj otoka i otočne baštine, osmislio je projekt Urboarhipelag. Pojednostavljeno 
do kraja, prema toj zamisli, otoci postaju dijelovi grada, gradska predgrađa u moru. Da bi tako funkcionirali, potrebna su mnoga inventivna rješenja u svim sferama, od prometa do obrazovanja i funkcioniranja rada javnih službi. Ta rješenja nisu ni nemoguća ni bitno skuplja. Jedino što ih uvjetuje jest pristanak državnih i lokalnih službenika na nove ideje, inovacije i novi pristup. U realizaciji jedne takve koncepcije bilo bi mjesta za sve: rezidentne otočane bez obzira na životnu dob, poduzetnike s otokâ i povratnike, istraživače otočane i neotočane. Na sličnim temeljima bio je postavljen i projekt Arhipelogos.

U svakom slučaju, za male otoke nema brzih rješenja. Ako se stanje i bude mijenjalo, a hoće, ti će procesi, ne dogodi li se neko čudo, teći sporo. I zbog toga se ne bi trebalo pretjerano ljutiti. Svi bismo htjeli promjene odmah. Nitko, a osobito otočani, nema mnogo vremena pred sobom. No gledano iz filozofske perspektive, ni svi naši pradjedovi nisu dočekali plodove svoga truda, pa su ipak radili kao da će živjeti vječno. Nije li to i naš zadatak? Trebamo li odustati zato što nećemo doživjeti ono o čemu sanjamo i za što radimo? Mislim da odgovor nije potreban. To što je vrijeme u kojem živimo tobože takvo da svi moramo imati sve i odmah velika je obmana. Svi su, u svakom vremenu, isto tako mislili. U petnaestak tisuća godina postojanja hrvatski su otoci i njihovi stanovnici doživjeli mnoge promjene i prilagodbe i sve su bile spore: od prenošenja poruka dimom do sms-a, od prometanja na splavi do superbrzih brodova. No ono što se nikada nije promijenilo, i sigurno neće do jednoga novog diluvija, istina je da je život na otocima uvijek bio drugačiji i rijetko lagan. Moj je stav, usprkos svemu, da tako treba i ostati, i da je takav stav dobro polazište za budućnost. 